\title{
Does troncular vagotomy modify the proliferative gastric lesions induced in rats by duodenogastric reflux ${ }^{1}$ ?
}

\author{
A vagotomia troncular modifica as lesões proliferativas gástricas induzidas em ratos \\ pelo refluxo duodenogástrico?
}

\author{
Paulo Antônio Rodrigues ${ }^{2}$, Shoiti Kobayasi ${ }^{3}$, Maria Aparecida Marchesan Rodrigues ${ }^{4}$ \\ 1. Research performed at Department of Pathology and Surgery \& Orthopedics of Botucatu Medical School, UNESP. Brazil. \\ 2. PhD, Department of Surgery \& Orthopedics Botucatu Medical School, UNESP. Brazil. \\ 3. Full Professor, Department of Surgery \& Orthopedics of Botucatu Medical School, UNESP. Brazil. \\ 4. Full Professor, Department of Pathology of Botucatu Medical School, UNESP. Brazil.
}

\begin{abstract}
Purpose: to investigate if combining VT to DGR through the pylorus can modulate the biological behavior of PL induced by DGR and to verify if TV alone can induce morphologic lesions in the gastric mucosa. Methods: 62 male Wistar rats were assigned to four groups: 1 - Control (CT) gastrotomy; 2 - Troncular Vagotomy (TV) plus gastrotomy; 3 Duodenogastric reflux through the pylorus (R) and 4 - Troncular vagotomy plus DGR (RTV). The animals were killed at the 54 week of the experiment. DGR was obtained by anastomosing a proximal jejunal loop to the anterior gastric wall. TV was performed through isolation and division of the vagal trunks. Gastrotomy consisted of $1 \mathrm{~cm}$ incision at the anterior gastric wall. PL were analyzed gross and histologically in the antral mucosa, at the gastrojejunal stoma and at the squamous portion of the gastric mucosa. Results: Groups R and RTV developed exophytic lesions in the antral mucosa $(\mathrm{R}=90.9 \%$; RTV=100\%) and at the gastrojejunal stoma $(\mathrm{R}=54.54 \%$; RTV=63.63\%). Histologically they consisted of proliferative benign lesions, without cellular atypias, diagnosed as adenomatous hyperplasia. Both groups exposed to DGR presented squamous hyperplasia at the squamous portion of the gastric mucosa $(\mathrm{R}=54.5 \%$; $\mathrm{RTV}=45.4 \%)$. TV, alone, did not induce gross or histological alterations in the gastric mucosa. TV did note change the morphologic pattern of the proliferative lesions induced by DGR.

Conclusions: DGR induces the development of PL in the pyloric mucosa and the gastrojejunal stoma. TV does not change the morphologic pattern of the proliferative lesions induced by DGR. TV alone is not able to induce morphologic lesions in the gastric mucosa.
\end{abstract}

Key words: Vagotomy, Truncal. Duodenogastric Reflux. Hyperplasia. Rats.

\section{RESUMO}

Objetivo: investigar se a adição da VT ao RDG através do piloro, interfere no comportamento biológico das LP induzidas pelo RDG e observar se a VT isoladamente leva ao desenvolvimento de lesões morfológicas na mucosa gástrica. Métodos: Foram utilizados 62 ratos Wistar machos, distribuídos em quatro grupos experimentais: 1- Controle (CT) Gastrotomia; 2- Vagotomia Troncular + gastrotomia (VT); 3-Refluxo duodeno-gástrico (R) e 4- RDG através do piloro e VT (RTV). Os animais foram sacrificados na 54 a semana do experimento. O RDG foi obtido através de anastomose do jejuno proximal com a parede gástrica anterior. A vagotomia troncular foi realizada através da dissecção e divisão dos troncos vagais. A gastrotomia consistiu de secção e síntese de um cm na parede gástrica anterior. As LP foram analisadas macroscopicamente e histologicamente na mucosa gástrica, na anastomose gastrojejunal e no estômago escamoso. Resultados: Os grupos R e RVT desenvolveram lesões exofíticas na mucosa do antro gástrico (R=90,9\% e RVT=100\%) e na anastomose gastrojejunal $(\mathrm{R}=54,5 \%$ e $\mathrm{RVT}=63,6 \%)$ que se caracterizaram no exame histológico por lesões proliferativas epiteliais benignas, sem atipias celulares, diagnosticadas como hiperplasia adenomatosa. Na região do estômago escamoso, ambos os grupos expostos ao RDG apresentaram hiperplasia escamosa ( $\mathrm{R}=54,5 \%$ e RVT=45,4\%). A VT não modificou o padrão histopatológico das LP induzidas pelo RDG. Os grupos VT e CT não apresentaram alterações macroscópicas ou histológicas significativas. Conclusões: o RDG induz o desenvolvimento de lesões proliferativas (LP) benignas na mucosa do antro gástrico e na anastomose gastrojejunal. A VT isoladamente não induz alterações proliferativas na mucosa gástrica e não modifica as características morfológicas das LP induzidas pelo RDG através do piloro.

Descritores: Vagotomia Troncular. Refluxo Duodenogástrico. Hiperplasia. Ratos. 


\section{Introduction}

Gastric carcinogenesis is a complex process, which involves the participation of multiple factors ${ }^{1,2}$. Hypochlorhydria, usually resulting from destruction of the gastric mucosa by long standing chronic inflammation, has been pointed as an important factor in the chain of events leading to gastric cancer ${ }^{3}$. High intragastric $\mathrm{pH}$ allows bacteria overgrowth and they can convert nitrates to nitrites, leading to the endogenous formation of $N$-nitroso compounds, which are powerful carcinogens ${ }^{4}$. Hypochlorhydria can also result from surgical procedures for the treatment of peptic ulcer. Troncular vagotomy (TV) associated to a draining procedures, like as pyloroplasty or gastroenteroanastomosis has been used in emergency situations such as treatment of perforated or hemorrhagic peptic ulcer in patients who do not support more extensive procedures ${ }^{5}$. Alterations in gastric physiology, like a raise in intragastric $\mathrm{pH}$ may result from $\mathrm{TV}^{3}$. Moreover, the association of TV to draining procedures can enhance the risk of gastric carcinogenesis. The deleterious effects of biliopancreatic secretions on the gastric mucosa have been investigated by several authors $6,7,8$. In a previous study ${ }^{9}$, we have observed direct correlation between duodenogastric reflux and the development of epithelial proliferative lesions in the pyloric mucosa. However, the lesions induced by the duodenogastric reflux were a benign condition, since they did not present cellular atypia or mural invasion and were reversible with interruption of duodenogastric reflux. Therefore, the aim of present study is to investigate if combining TV to the experimental model of duodenogastric reflux (DGR) can enhance the progression of proliferative lesions to malignancy, as well to evaluate if TV, by itself, can induce morphological alterations in the gastric mucosa.

\section{Methods}

Sixty-two male Wistar rats weighing 150 g were fed a standard maintenance diet (Nuvilab-CR-NUvital Nutrientes Prodvet Ltd., Brazil) and tap water ad libitum. The animals were kept under standard conditions in a controlled room kept at a $22 \pm 2{ }^{\circ} \mathrm{C}$ and a $12 / 12 \mathrm{~h}$ light/ dark cycle. After initial acclimation, they were randomly assigned into four groups according to the surgical procedure (Figure 1).

Control (CT) submitted to a laparotomy and gastrotomy at stomach anterior wall.

Troncular Vagotomy (TV) submitted to a division of anterior and posterior vagal trunks and gastrotomy at the stomach anterior wall.
Reflux (R) submitted to a surgical procedure for induction of duodenogastric reflux (DGR).

Reflux plus Troncular Vagotomy (RTV) submitted to the same surgical procedures of the $\mathrm{R}$ group plus bilateral Troncular vagotomy. After intra-peritoneal anesthesia with pentobarbital sodium (30 mg/kg body wt) and laparotomy the following procedures were performed (Figure 2).

CT group: gastrotomy (1cm extension) next to the transition between squamous and glandular mucosa and closed with continuous suture.

TV group: gastrotomy in a similar way of CT group and at sequence the anterior and posterior vagal trunks were dissected, isolated and divided.

R group: an anastomosis was constructed between a jejunal segment (four $\mathrm{cm}$ ahead of beginning of jejunum) and stomach anterior wall, at sequence the jejunum was divided and both cut ends had been closed one $\mathrm{cm}$ previous the gastrojejunal anastomosis, in order to allow the flow of the duodenal content to the stomach.

RTV group: to the same procedures of the R group plus division of vagal trunks. The same surgeon, with polypropylene 6-0 sutures, performed all procedures (Figure 2).

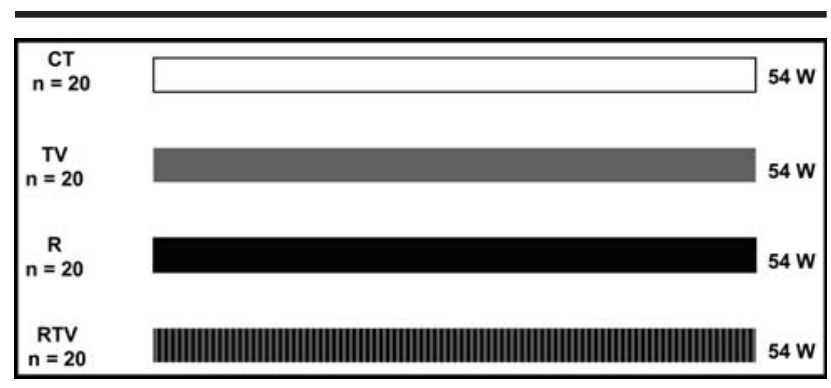

FIGURE 1 - Experimental design

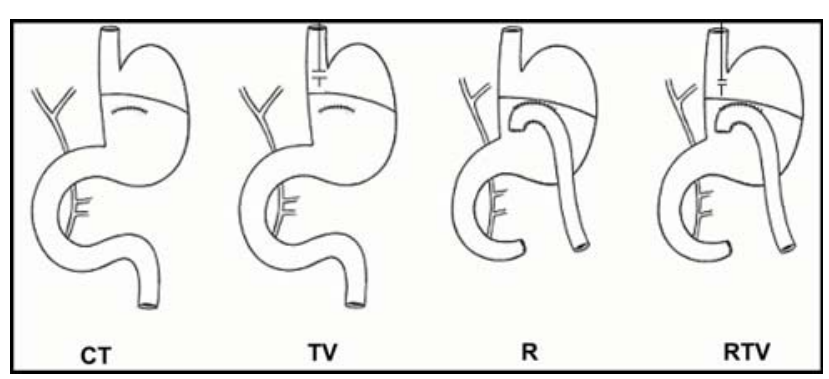

FIGURE 2 - Schematic illustration of surgical procedures 
After the surgery, the animals had access only to water; solid food was allowed after 24h. Body weight was measured weekly and necropsies were performed on the animals found dead during the experiment. All animals were killed under sodium pentobarbital (30 mg/ $\mathrm{kg}$ body wt) anesthesia at the $54^{\mathrm{Th}}$ week. The abdominal cavity was examined for the presence of ascites, fistulae, prominent lymphatic nodules and carcinomatosis. The stomach was removed, opened along the great curvature, rinsed in saline solution and examined. The lesions found in the glandular stomach and at gastrojejunal stoma were photographed and their macroscopic characteristics registered. The specims were spread on a cork plate on the serosal surface and fixed by immersion in $10 \%$ buffered formalin. Each stomach was sectioned into successive longitudinal cuts including the oxyntic and the pyloric mucosa. The gastrojejunal portion was submitted to successive transverse cuts including the oxyntic mucosa and the jejunal loop. Samples from the squamous portion of the stomach were taken separately. The specimens were embedded in paraffin and stained with hematoxylin/eosin. The histopatological analysis was performed without the knowledge of the experimental groups. Comparisons between the groups were performed by the Chi-Square test. Differences were assumed to be significant when $\mathrm{p}<0.05$. The study was approved by the Ethics Committee on care and use of laboratory animals of the National Research Council.

\section{Results}

The effective number of animals in each group was CT $n=20, \operatorname{VT} n=20, R n=11$ and RTV n=11. There were 18 deaths during the experiment due to postoperative complications, intra-abdominal abscesses and malnutrition. No lesions were found in the gastric mucosa in the group submitted only to troncular vagotomy (TV) and the control group (Figure 3).

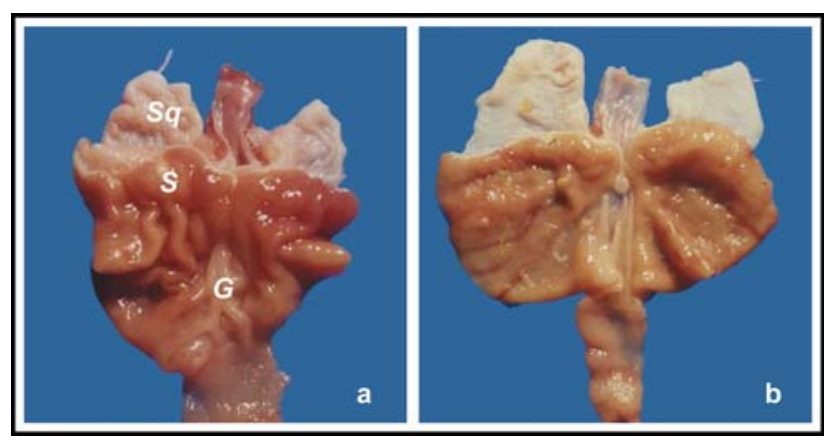

FIGURE 3 - Macroscopy of surgical specimens from the control (a) and Troncular Vagotomy (b) groups. $S$, scar; $S q$, squamous stomach; $G$, glandular stomach
In contrast, both groups submitted to duodenal reflux (RTV and $\mathrm{R}$ ) presented huge exophytic or polypoid lesions, frequently with central ulceration, in the pyloric mucosa and at the gastrojejunal stoma (Figure 4). All the animals from RTV $(n=11)$ and 10 out of 11 rats (90.9\%) from $\mathrm{R}$ group developed exophytic lesions in the pyloric mucosa. Similar lesions were found at the gastrojejunal stoma in 7 out of 11 rats (63.6\%) from RTV group and in 6 of 11 rats (54.5\%) from $\mathrm{R}$ group.

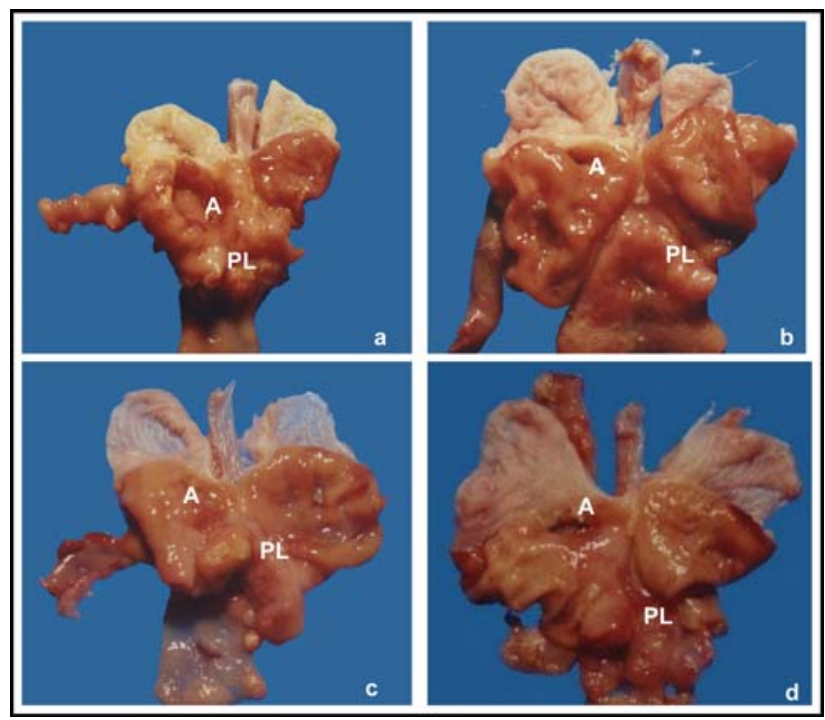

FIGURE 4 - Macroscopy of surgical specimens from Reflux ( $\mathrm{a}$ and $\mathrm{b}$ ) and Reflux plus Troncular Vagotomy (c and d) groups. $A$, anastomosis; $P L$, polypoid lesion

No remarkable macroscopic alterations were found at the squamous portion of gastric mucosa. Data for the distribution of the histological lesions in the pyloric mucosa and at gastrojejunal anastomosis are shown in table 1. The exophytic lesions observed in the pyloric mucosa were similar in both R and RTV groups and consisted of proliferating glandular structures and foveolar epithelium, with cystic dilatations, without cellular atypia. These lesions did not invade the muscular layer. They were diagnosed as adenomatous hyperplasia (Figure 5). No adenocarcinomas were found in both groups submitted to duodenogastric reflux (R and RTV). The polypoid and nodular lesions found at the gastrojejunal anastomosis consisted of proliferation of the glandular and foveolar epithelium, without cellular atypias. Endophytic growth within the anastomosis was seen. Squamous hyperplasia, characterized for thickening of squamous epithelium and hyperkeratosis, was observed in the squamous mucosa in both groups ( $R$ and RTV) exposed to duodenogastric reflux (Table 1). 


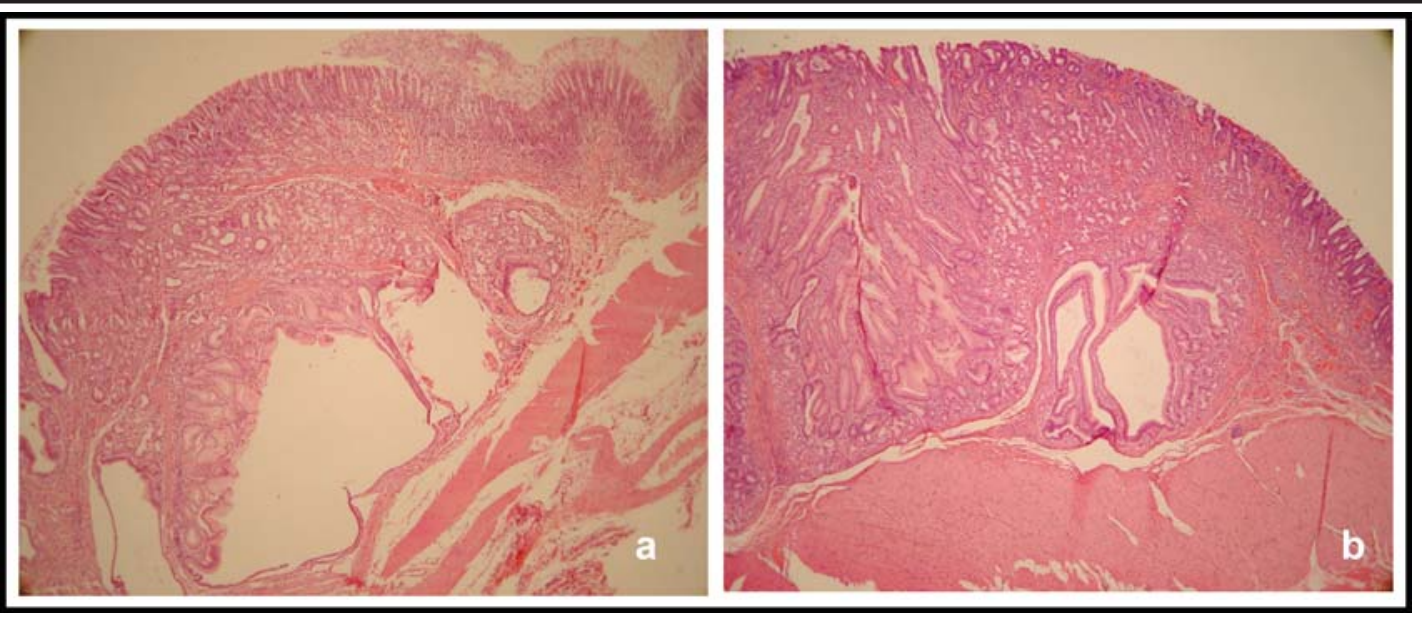

FIGURE 5 - Histology of adenomatous hyperplasia in the pyloric mucosa. Reflux (a) and Reflux plus Troncular Vagotomy (b) groups. HE 100x

TABLE 1 - Frequency (\%) and distribution of histological lesions diagnosed in the four experimental groups

\begin{tabular}{lllll}
\hline Groups & $\mathbf{n}$ & $\begin{array}{l}\text { Pyloric } \\
\text { Mucosa }\end{array}$ & Anastomosis & $\begin{array}{l}\text { Squamous } \\
\text { Epithelium }\end{array}$ \\
\hline & & $\mathrm{AH}$ & $\mathrm{AH}$ & $\mathrm{SH}$ \\
$\mathrm{CT}$ & 20 & 0 & 0 & 0 \\
$\mathrm{TV}$ & 20 & 0 & 0 & 0 \\
$\mathrm{R}$ & 11 & $10(90,9)^{*}$ & $6(54.5)^{* *}$ & $6(54.5)^{* * *}$ \\
$\mathrm{RTV}$ & 11 & $11(100)^{*}$ & $7(63.6)^{* *}$ & $5(45.4)^{* * *}$ \\
\hline
\end{tabular}

n, effective no of animals; AH, adenomatous hyperplasia; SH, squamous hyperplasia; CT, Control group; TV, Troncular Vagotomy group; R, Duodenogastric Reflux group; RTV, Duodenogastric Reflux plus Troncular Vagotomy group *p>0,3 **p>0,3 ***p>0,3.

\section{Discussion}

The results of present study demonstrate that duodenogastric reflux (DGR) led to the development of proliferative epithelial lesions in the pyloric mucosa and at gastrojejunal stoma in both R and RTV groups. These lesions could be related to the prolonged contact of the gastric mucosa with the components of bile and pancreatic secretion. They probably result from the deleterious action of the DGR components on the mucus layer of the gastric epithelium ${ }^{6,8,9,10}$. The detergent action of the components of bile can modify the permeability of the mucosa enhancing back-diffusion of chemical substances into the mucosa. It was been showed in rats that bile and the pancreatic juice are rich in growing factors similar to the epidermic growth factor ${ }^{11}$. Another possibility is that the proliferative lesions may correspond to a reactive process of cell hyperplasia to the damage induced by the components of the duodenal reflux to the gastric mucosa. The glandular hyperplasia would increase mucus production in order to adapt the mucosa to the deleterious environment of reflux. In a previous study ${ }^{9}$, we have demonstrated direct correlation between the glandular hyperplasia and duodenogastric reflux, since the proliferative lesions were reversible with interruption of reflux. In the present study troncular vagotomy (TV), alone, did not induce any lesions in the gastric mucosa and it did not modify the morphologic picture of the proliferative lesions induced by DGR through the pylorus. One would expect that the denervation could enhance the progression of the epithelial proliferative lesions to malignancy, since the defensive factors of the gastric mucosa, such as blood flow, mucus secretion and the renewal of the epithelial cells depend on the neural integrity ${ }^{3}$. Moreover, epidemiological studies suggest that the vagotomy can increase the risk for development of the gastric cancer 12, 13. Experimental studies also suggest that vagotomy can favor the development of gastric cancer. Stegmann et al ${ }^{14}$ obtained gastric cancer in rats submitted to troncular vagotomy associated to a draining procedure in the absence of chemical carcinogens. Tatsuta et al ${ }^{4}$ reported that the vagotomy significantly increased the incidence of gastric adenocarcinomas in rats treated with $\mathrm{N}$-methyl-N'-nitro-N- nitrosoguanidine (MNNG). Our results are in contrast to these studies since we did not observe any relationship between troncular vagotomy, alone or combined to duodenogastric reflux(DGR) and the development of gastric adenocarcinoma. This is not unexpected finding since the histological criteria for the 
diagnosis of the lesions are not uniform ${ }^{7}$. In the present study, the histological diagnosis of malignancy of the lesions was based on the presence of cellular atypia and local invasion of the prolierating structures. Another possibility to explain the differences between our results and those reported in the literature could be the different rat strains used in the studies. We worked with Wistar rats wich are well known for the variable susceptibility to chemical cancerigens ${ }^{15}$.

\section{Conclusions}

The reflux of duodenal contents induces the development of proliferative benign lesions in the pyloric mucosa and at the gastrojejunal anastomosis. Troncular vagotomy alone did not promote the development of proliferative alterations in the gastric mucosa and it did not modify the morphologic picture of the proliferative lesions induced by reflux of duodenal contents through the pylorus in the pyloric mucosa and at a gastrojejunal stoma.

\section{References}

1. Correa P. Human gastric carcinogenesis: a multistep and multifatorial process- First American cancer society award lecture on cancer epidemiology and prevention. Cancer Res. 1992; 52: 6735- 40.

2. Nardone G. Molecular basis of gastric carcinogenesis. Aliment Pharmacol Ther. 2003; 17: 75-81.

3. Kaminishi M, Oohara T, Chiu ML, Aoki F, Yamaguchi $\mathrm{H}$, Shimoyama S. Severe gastric mucosal changes following vagotomy with duodenogastric reflux. J Clin Gastroenterol. 1992; 14(Suppl. 1): 515-24

4. Tatsuta M, Yamamura H, Iishi H, Ichii M, Noguchi S, Baba M, Taniguchi H. Promotion by vagotomy of gastric carcinogenesis induced by N-methyl-N'-nitro$\mathrm{N}$-nitrosoguanidine in Wistar rats. Cancer Res. 1985; 45(1): 194-7.

5. Tsugawa K, Koyawagi N, Hashizume M, Tomikawa M, Akahoshi K, Ayuama K, Wada H, Tandue K, Sugimachi $\mathrm{K}$. The therapeutic strategies in performing emergency surgery for gastroduodenal ulcer perforation in 130 patients over 70 year of age. Hepatogastroenterology. 2001; 48: 156-62.

6. Mason RC. Duodenogastric reflux in rat gastric carcinoma. Br J Surg. 1986; 73: 801-3.

7. Kobayasi S, Tatematsu M, Ogawa K, Camargo JLV, Rodrigues MAM, Ito N. Reversibility of adenomatous hyperplasia in the gastric stump after diversion of bile reflux in rats. Carcinogenesis. 1991; 12: 1437-43.

8. Miwa K, Fujimura T, Hasegawa H, Kosaka T, Miyata R, Miyasaki I, Hattori T. Is bile or pancreaticduodenal secretions related to gastric carcinogenesis in rats with reflux through the pylorus? Cancer Res Clin Oncol. 1992; 118: 570-4.

9. Rodrigues PA, Naresse LE, Leite CVS, Rodrigues MAM, Kobayasi S. O refluxoduodeno-gástrico (RDG) através do piloro, induz lesões proliferativasgástricas em ratos?Acta Cir Bras. 2002; 17(3): 160-7.

10. Rodrigues MAM, Kobayasi S, Naresse LE, Leite CVS, Nakanishi H, Imai T, Tatematsu M. Biological differences between reflux stimulated proliferative lesions and $\mathrm{N}$-methyl-N'-nitro-N-nitrosoguanidine induced carcinomas in Wistar rats. Cancer Letters. 1999; 145: 85-91.

11. Jaworek J, Konturek SJ. Distribution, release, and secretory activity of epidermal growth factor in the pancreas. Int J Pancreatol. 1990; 6: 189-204.

12. Caygill CP, Knowles RL, Hall R. Increased risk of cancer mortality after vagotomy for peptic ulcer: a preliminary analysis. Eur J Cancer Prev. 1991;(1): 35-7.

13. Caygill CP, Hill MJ, Kirkham JS, Northfield TC. Mortality from gastric cancer following gastric surgery for peptic ulcer. Lancet. 1986; 1(8487): 929-31.

14. Stegemann B. Carcinogenesis following vagotomy. Experimental long-term animal studies. Fortschr Med. 1982; 100(13): 586-91.

15. Ohgaki H, Kawachi T, Matsukura N, Morino K, Miyamoto M, Sugimura T. Genetic control of susceptibility of rats to gastric carcinoma. Cancer Res. 1983; 43: 3663-9.

\section{Correspondence:}

Paulo Antônio Rodrigues

Faculdade de Medicina de Botucatu-UNESP

Departamento de Cirurgia e Ortopedia.

18618-970 Botucatu - SP Brazil

paulor@fmb.unesp.br
Conflict of interest: none Financial source: none

Received: January 15, 2007

Review: February 12, 2007

Accepted: March 16, 2007

\section{How to cite this article}

Rodrigues PA, Kobayasi S, Rodrigues MAM. Does troncular vagotomy modify the proliferative gastric lesions induced in rats by duodenogastric reflux? Acta Cir Bras. [serial on the Internet] 2007 May-June;22(3). Available from URL: http://www.scielo.br/acb 